\title{
SeaGIS Abruzzo: A publicly available atlas of marine uses and natural resources in the Adriatic Sea Region
}

\author{
Carla Ippoliti, ${ }^{1}$ Alessio Di Lorenzo, ${ }^{1}$ Riccardo Caprioli, ${ }^{1}$ Sandro Pelini, ${ }^{1}$ Annamaria Conte, ${ }^{1}$ \\ Fernando D'Anselmo, ${ }^{2}$ Barbara Alessandrini, ${ }^{1}$ Susanna Tora, ${ }^{1}$ Carla Giansante ${ }^{1}$ \\ ${ }^{1}$ Istituto Zooprofilattico Sperimentale dell'Abruzzo e del Molise "G. Caporale”, Teramo; ${ }^{2}$ Fish Economy and \\ Agricultural Credit Service, National and Regional Fish Policies Office, Agricultural and Rural, Food, \\ Hunting, Fishing, Emigration, Development Policies Directorate, Abruzzo Region, Pescara, Italy
}

\begin{abstract}
In the Adriatic Sea, the European Union supported a cross-border cooperation research program, during which digital spatial data on shellfish production and relaying areas, regulated conditions on fishing activities, protected areas and restocking structures, administrative boundaries and sea bottom characteristics, were collated from digital repositories in various institutions and paper documents. A web-based
\end{abstract}

Correspondence: Carla Ippoliti, Istituto Zooprofilattico Sperimentale dell'Abruzzo e del Molise "G. Caporale", Campo Boario, 64100 Teramo, Italy.

Tel.: +39.0861.3321

E-mail: c.ippoliti@izs.it

Key words: WebGIS; Adriatic Sea; Fishery; Marine spatial management; Abruzzi Region.

Contributions: CI, CG, FDA participated to the ECOSEA project and conceived the idea of a web system collecting and sharing data of Abruzzi region; ADL designed and developed the webGIS system; SP and ST prepared geographical data; CI, RC, AC, BA, CG wrote the manuscript. All authors contributed critically to the drafts and gave final approval for publication.

Conflict of interest: the authors declare no potential conflict of interest.

Funding: this work was partly supported by the Abruzzi Region, Servizio Economia Ittica e Credito Agrario, Ufficio Politiche Ittiche Nazionali e Regionali, Direzione Politiche Agricole e di Sviluppo Rurale, Alimentare, Caccia, Pesca, Emigrazione and by the funding of ECOSEA Project IPA Adriatic cross-border cooperation program, Intervention Area 2 - Protection and enhancement of the marine environment and coastline.

Received for publication: 4 May 2018

Revision received: 1 October 2018.

Accepted for publication: 1 October 2018.

(C) Copyright C. Ippoliti et al., 2018

Licensee PAGEPress, Italy

Geospatial Health 2018; 13:705

doi:10.4081/gh.2018.705

This article is distributed under the terms of the Creative Commons Attribution Noncommercial License (CC BY-NC 4.0) which permits any noncommercial use, distribution, and reproduction in any medium, provided the original author(s) and source are credited. geographical information system was developed to share data of the sea facing the Abruzzi region and to explore the spatial distribution of marine resources and maritime activities, thus focussing and facilitating fisheries management and providing a potential support to the regional planning of resource exploitation.

Video link

https://www.youtube. com/watch?v=2axYJQFII-0

\section{Background}

Marine coastal and offshore areas are subject to a growing pressure by numerous stakeholders for different purposes, including harbours and shipping, production of energy from renewable sources, exploitation of oil and natural gas deposits, sediment extraction and disposal, fisheries and aquaculture, environmental protection and tourism (De Freitas and Tagliani, 2009; Katsanevakis et al., 2011). This convergence of multiple interests poses new challenges to make the development of human activities compatible with the safeguard of natural resources, as they compete for the same valuable space.

In many cases, the attempts to balance different interests and assess compatibilities have been hampered by difficulties using available data and information and by sectoral policies adopted by institutions and stakeholders.

This does not mean that all the activities carried out in sea areas are not regulated or that no rational or fair space allocation is performed: on the contrary, many regulations exist, but they are predominantly confined to conventional economic sectors (Douvere, 2008) or traditionally managed case-by-case. In the European Union (EU), a framework for Maritime Spatial Planning (MSP) was established by Directive 2014/89/EC, which integrated Directive 2008/56/EC, also known as the Marine Strategy Framework Directive. These Directives lay down guidelines for achieving compatibility between the development of economic activities and the need to safeguard marine resources for future generations (Piroddi et al., 2015).

Fisheries are one of the economic activities that have to face a competition for space, due to fleet overcapacity problems, decline of fish stocks and reduced profitability. Fishing areas should be defined by a flexible approach, in accordance with the changes in fish stock distribution patterns, while aquaculture activities require specific reserved areas (Aswani and Lauer, 2006).

A research project, related to this context named Protection, improvement and integrated management of the sea environment and of cross border natural resources (ECOSEA), was developed 
between 2012 to 2016 as part of the framework of the Instrument for Pre-accession Assistance Adriatic cross-border cooperation program, Intervention Area 2 - Protection and enhancement of the marine environment and coastline (http://www.ecosea.eu/it/). The ECOSEA project involves six Italian regions, two counties in Croatia, and the Ministry of Environment, Forestry and Water Administration of Albania. Its general objective is an improved management of the natural resources of the Adriatic Sea through the cooperation between border regions, within the common framework of the EU Common Fisheries Policy. One of the project specific objectives is the collection of digitalized information on the use of coastal and offshore areas in the Adriatic Sea, with particular attention to fisheries activities.

In the Abruzzi framework of ECOSEA activities, the authors developed a geographic database to collect and retrieve data and spatial information concerning the exploitation of marine and fishery resources in the stretch of the Adriatic Sea facing the Abruzzi region, central Italy. A web-based GIS application, named SeaGIS Abruzzo was developed to easily display and share the collected data with all possible local stakeholders, and was made available as thematic interactive geographical maps.

WebGIS allows data integration across diverse traditional disciplines and provides a framework of information collected for a variety of specific purposes (Carollo et al., 2009).

This spatial information can be gathered from many sources and assembled in a unique WebGIS application (Katsanevakis et al., 2011), which can represent the core of decision support systems for environmental and marine management (Tuda et al., 2014) or can allow the simulation of alternative management scenarios to evaluate and prioritise interventions. A spatially organised database, together with web-based visualisations, may intuitively reveal possible spatio-temporal trends or relationships that would be more difficult to discover in tabular or other formats (De Freitas and Tagliani, 2009). Data and webGIS are elements to be integrated with other relevant data (biological indicators, water quality, socio-economic features, remotely sensed data) (Ruddick et al., 2014) and implemented in numerical modelling (Soma et al., 2013; Piroddi et al., 2015; Brigolin et al., 2017) to quantitatively support the MSP.

The WebGIS system simplifies and unifies access to data for managers, stakeholders and politicians and facilitates ecosystembased management. Even if the interaction among these actors is not straightforward, the knowledge exchange among scientists and decision makers would be very relevant (Cvitanovic et al., 2015), with the common goal of maintaining marine ecosystems in healthy, productive and resilient conditions (Katsanevakis et al., 2011).

\section{Content of SeaGIS application}

Data for the coastal area facing the Abruzzi region were collected on the following thematic areas: i) Protected areas and restocking structures; ii) Sanitary classification of shellfish production and relaying areas; iii) Regulated areas; iv) Areas subject to environmental impact; v) Administrative areas; vi) Characteristics of the sea bottom.

To develop the features, a standardized workflow was adopted: i) assessment of most recent legislation and identification of relevant data for the region of interest (spatial selection of the information); ii) digitalisation of the geographical boundaries of the ele- ments; iii) population of attribute tables; iv) production of metadata; v) validation of information.

The list of layers, the source of the data and a brief description of the layer content are reported in the following Table 1. Each layer is equipped with references to the original source of data, provided as links in the attribute tables.

\section{Description of SeaGIS application and user access}

The WebGIS application is publicly accessible by clicking on the SeaGIS Abruzzo link, provided in the Abruzzi Region fisheries homepage (http://www.regione.abruzzo.it/pesca/) or directly at http://mapserver.izs.it/gis_ecosea/. The interface allows to navigate the data, the base maps and allows to overlay the layers. The application is in Italian language, being dedicated to local stakeholders.

The layers in SeaGIS Abruzzo are exposed as open geospatial consortium (OGC) standard web services, that is Web Map Service (WMS). The services containing each layer are exchanged in image or vector format on the internet, and can be integrated into other applications, in many system platforms or into desktop geographical software. Similarly, the SeaGIS Abruzzo application can receive and display data from third party sources provided as OGC compliant web services. The metadata files associated with each layer are accessible by clicking on the $M$ symbol next to the layer name: general information on the layer, date of creation, language, geographical extent, a brief description of the layer content, and the reference person or organisation responsible for the creation and maintenance of the metadata are available.

\section{Potential use of SeaGIS application for the man- agement of marine resources in Abruzzi Region}

The MSP Directive 2014/89/EC was adopted by the Italian Government with the Regulation n. 201 of 17 October 2016. Since January 2016, SeaGIS was made available to the permanent advisory Regional Committee on Fisheries and Aquaculture of the Abruzzi region as a complementary tool to support decisions on the allocation of marine space.

The coast of Abruzzi region is about $120 \mathrm{~km}$ long in the central part of Adriatic Sea. It accommodates space for several human activities, including fisheries and aquaculture (production and harvesting areas of mussels and other bivalve molluscs), together with marine and terrestrial protected areas. In the coastal zone, within the territorial waters (12 nautical miles), platforms for oil and gas extraction and related pipelines are present as well as dumping areas and underwater sewage.

A first potential application of the SeaGIS system was tested in the area facing the Giulianova harbour, where new sites for shellfish farming were identified according the complexity of already existing maritime activities as well as considering the sanitary status of edible Bivalves Molluscs in the farms and natural banks in the area (Figure 1).

In the system, indeed, the layer Classificazione delle acque per la molluschicoltura reports the sanitary status of the molluscs according to the EU Regulation 854/2004. The Regulation establishes the official control programmes for bivalve molluses and it sets out the requirements for production and placing on the market 
of live bivalve molluses in the EU. This ensures that marketed shellfish are either derived from high quality areas (class A, green coloured polygons) or appropriately treated prior to sale to ensure the reduction of microbiological pollutants (class B, yellow colour, and class $\mathrm{C}$, in red and not present along Abruzzi coast).

\section{Outlook}

SeaGIS Abruzzo represents a focus point for marine spatial planning in the Abruzzi region, improving the preparedness toward the implementation of the most recent legislation. The system facilitates the updates of such MSP with specific information on the status of marine resources, actually becoming a management tool for food safety and animal health. Such integrated system can also be useful to plan effective actions facilitating the adoption of appropriate targets for monitoring plans and helping the description of future scenarios in risk modelling. These data are the core dataset needed to be combined in spatial modelling able to assess

Table 1. List of SeaGIS Abruzzo layers, with data sources and a brief description of the layer content.

\begin{tabular}{|c|c|c|c|}
\hline Thematic area & Layer name & Description & Data source \\
\hline \multirow[t]{3}{*}{$\begin{array}{l}\text { Protected areas and } \\
\text { restocking structures }\end{array}$} & Seagrass meadows & $\begin{array}{l}\text { Locations where the presence of Cymodocea nodosa } \\
\text { has been notified }\end{array}$ & $\begin{array}{l}\text { Carla Giansante, scientific internal } \\
\text { report IZSAM 9840/2009 }\end{array}$ \\
\hline & Restocking structures & Artificial reefs for restocking & $\begin{array}{l}\text { Polygon digitalised from scientific reports } \\
\text { of Doc U.P. Pesca project (EC 2792/1999) }\end{array}$ \\
\hline & Protected Areas & $\begin{array}{l}\text { European inventory of Nationally designated areas, } \\
\text { holding information about protected areas. } \\
\text { The layer includes: the Marine Protected area } \\
\text { Torre del Cerrano, six Sites of Community Importance } \\
\text { in the coastal area and three natural reserves on the }\end{array}$ & $\begin{array}{l}\text { Original shapefile data at } \\
\text { http://www.eea.europa.eu/data-and-maps/ } \\
\text { data/nationally-designated-areas-national-cdda-8 } \\
\text { (accessed: 3rd December 2015) }\end{array}$ \\
\hline
\end{tabular}

$\begin{array}{lll}\begin{array}{l}\text { Classification of shellfish } \\ \text { production and relaying }\end{array} & \text { Mariculture } & \begin{array}{l}\text { Marine areas with mussel and other } \\ \text { areas }\end{array} \\ & \text { Mussel Classification molluscs breeding } & \begin{array}{l}\text { Sanitary classification of natural clam } \\ \text { (Chamelea gallina) banks }\end{array} \\ & & \end{array}$

Regulated areas $\quad$ Regulated Areas

Forbidden areas

\begin{tabular}{lll} 
Impacted areas & Explosive sites & Area with old or recent unexploded war devices \\
& $\begin{array}{l}\text { Dumping areas } \\
\text { Underwater sewage }\end{array}$ & Disposal sites of harbour dredged sediments \\
& Extension of sewer pipes and average load as & \\
\hline Administrative areas & Harbours & Major ports and harbours \\
& $\begin{array}{l}\text { Coastline and reef } \\
\text { breakwaters }\end{array}$ & Adriatic coastline at a national level of detail
\end{tabular}

Fishing sectors

Territorial waters

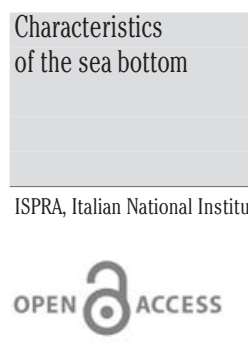

Wrecks

Bathymetry

\footnotetext{
ISPRA, Italian National Institute for Environmental Protection and Research; CNR, National Research Council.
}

Most relevant wrecks potentially dangerous for fisheries

Underwater depth of the Adriatic Sea, reference scale 1:750,000

Polygon digitalised from official documents of the local Harbour Office

Polygon digitalised from official documents of official institutions (Abruzzi provision no. 807 of 05.12.2014) activities (i.e. anchoring areas where transit, fishing and other activities are banned)

Areas in which fishing activities are prohibited due to territorial and sea bottom characteristics (pipelines, cables, platforms, bathing areas)

Polygon digitalised from official documents of the local Harbour Office

Polygon digitalised from official documents of the local Harbour Office.

Polygons designed at IZSAM, on the basis of 2014 prefaction to the notice to Mariners, Italian Navy Hydrographic Institute

Shape project Adriatic Atlas administrators Emilia Romagna Region Azienda Comprensoriale Acquedottistica SpA, Pescara

Shape project Adriatic Atlas administrators Emilia Romagna Region.

Original data collected from the ISPRA database Shape project Adriatic Atlas administrators Emilia Romagna Region.

The Italian coastline, edited by ISPRA, drawn by photointerpretation (1:5000 - 1:25.000 scale) from IT2006 flight (www.pcn.minambiente.it)

Fishing areas related to harbour fishing administrative entities Polygons digitalised at IZSAM, on the basis of D.P.R. ${ }^{1^{s t}}$ March 2005, n. 51

Territorial waters: a belt of coastal waters extending at most Shape project Adriatic Atlas administrators 12 nautical miles from the Italian baseline

- Emilia Romagna Region.

The drawing was carried out according to legislative instructions, but the result cannot be considered as official, since there is no official Italian territorial sea baseline

Points designed at IZSAM, on the basis of Italian Navy Hydrographic Institute and notice from the local Harbour Office

CNR - Institute of Marine Science (ISMAR), Bologna (Trincardi et al., 2014) 


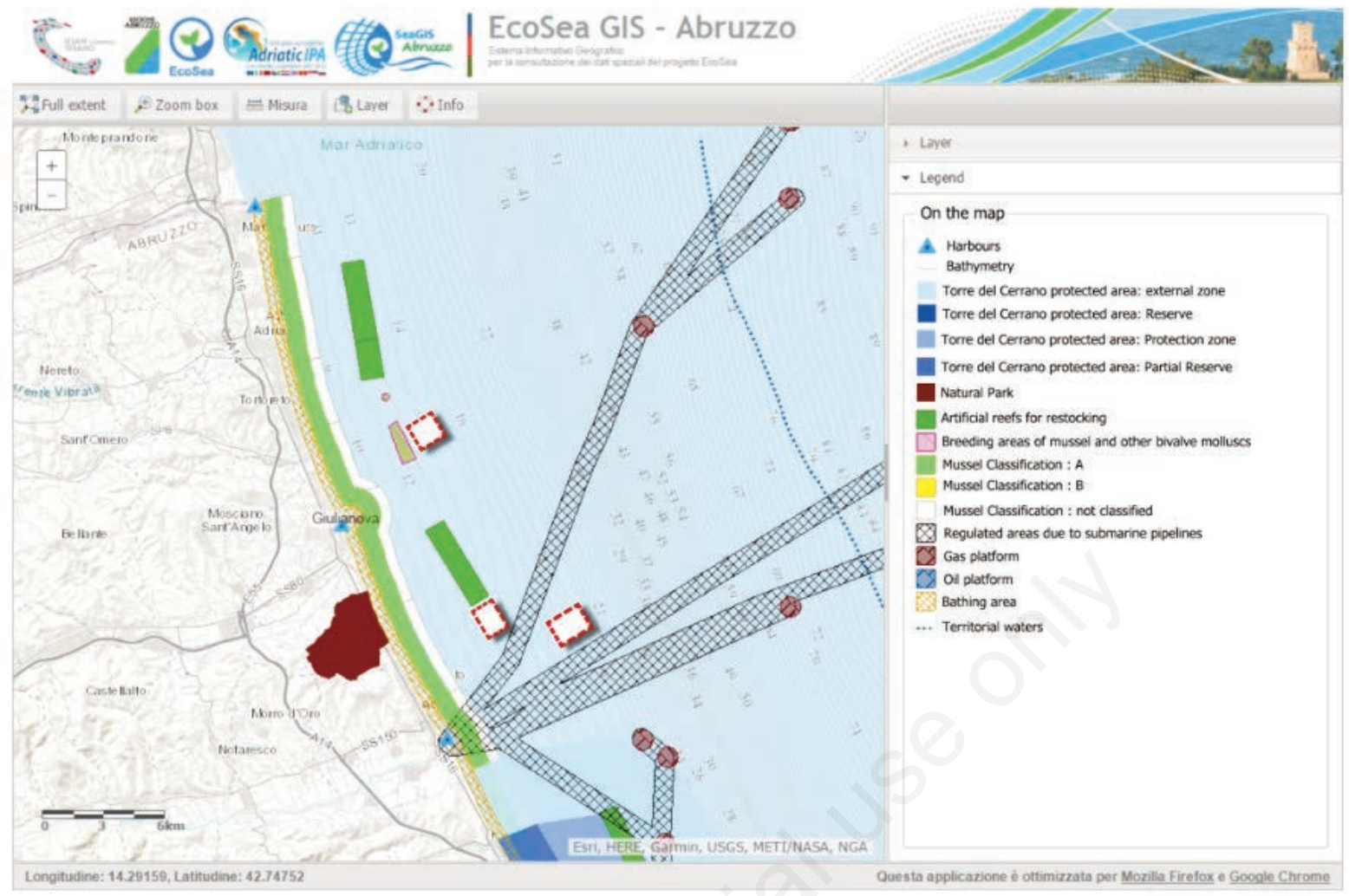

Figure 1. Potential sites for new shellfish farms (white square, red dashed border) identified near Giulianova harbour.

shellfish site suitability.

This communication consists of this text and a short video with the aims to share its content with a wider range of stakeholders and to facilitate the communication of WebGIS functionalities to government offices. The system background, the available datasets and the main functionalities and possible interactions are visualized in the video. It concludes with a practical session showing how the data from the WebGIS can be integrated into a local GIS desktop (QGIS) through a Web Map Service.

\section{Overall aim}

GIS represents a useful tool to implement the MSP, since it can display, overlap and analyse different types of information, comparing many data at the same time. Moreover, it has multi-scale capabilities, allowing the storage, manipulation and integration of large amounts of data and simplifying data maintenance and information sharing.

The WebGIS SeaGIS Abruzzo was developed to easily display and share the collected data concerning the exploitation of marine and fishery resources.

\section{Software}

Data did store into the Oracle $10 \mathrm{~g}$ Database Management System, directly connected to the GIS server (ESRI ${ }^{\circledR}$ ArcGIS Server 10.2). The information did then make available as standard
Representational State Transfer (ReST) Map Service, in the form of georeferenced map images (Web Map Service - WMS).

The client application was developed using ESRI ${ }^{\circledR}$ ArcGIS API for JavaScript to manage the layers and jQuery to realize the user interface and to perform AJAX calls to the server-side resources. The WebGIS client application was made publicly accessible with a generic browser and it integrated the high spatial resolution tiled map services of ESRI ${ }^{\circledR}$ ArcGIS Online. The WMS is available for users who want to consult the data independently from the WebGIS application. Metadata files did compiled using the Metadata Editor available on the INSPIRE Geoportal (inspire-geoportal.ec.europa.eu/). The video was produced with Camtasia Studio 9 software (TechSmith Corporation, Okemos, MI, USA).

\section{References}

Aswani S, Lauer M, 2006. Incorporating fishermen's local knowledge and behavior into Geographical Information Systems (GIS) for designing Marine Protected Areas in Oceania. Hum Organ 65:81-102.

Brigolin D, Porporato EMD, Prioli G, Pastres R, 2017. Making space for shellfish farming along the Adriatic coast. ICES J Mar Sci 74:1540-51.

Carollo C, Reed DJ, Ogden JC, Palandro D, 2009. The importance of data discovery and management in advancing ecosystembased management. Mar Policy 33:651-3.

Cvitanovic C, Hobday AJ, van Kerkhoff L, Wilson SK, Dobbs K, 
Marshall NA, 2015. Improving knowledge exchange among scientists and decision-makers to facilitate the adaptive governance of marine resources: A review of knowledge and research needs. Ocean Coast Manag 112:25-35.

De Freitas DM, Tagliani PRA, 2009. The use of GIS for the integration of traditional and scientific knowledge in supporting artisanal fisheries management in southern Brazil. J Environ Manage 90:2071-80.

Douvere F, 2008. The importance of marine spatial planning in advancing ecosystem-based sea use management. Mar Policy 32:762-71.

Katsanevakis S, Stelzenmüller V, South A, Sørensen TK, Jones PJS, Kerr S, Badalamenti F, Anagnostou C, Breen P, Chust G, D'Anna, Duijn M, Filatova T, Fiorentino F, Hulsman H, Johnson K, Karageorgis AP, Kröncke I, Mirto S, Pipitone C, Portelli S, Qiu W, Reiss H, Sakellariou D, Salomidi M, van Hoof L, Vassilopoulou V, Fernández TV, Vöge S, Weber A, Zenetos A, ter Hofstede R, 2011. Ecosystem-based marine spatial management: Review of concepts, policies, tools, and critical issues. Ocean Coast Manag. 54:807-20.

Piroddi C, Teixeira H, Lynam CP, Smith C, Alvarez MC, Mazik K, Andonegi E, Churilova T, Tedesco L, Chifflet M, Chust G,
Galparsoro I, Garcia AC, Kamari M, Kryvenko O, Lassalle G, Neville S, Niquil N, Papadopoulou N, Rossberg A, Suslin S, Uyarra MC, 2015. Using ecological models to assess ecosystem status in support of the European Marine Strategy Framework Directive. Ecol Indic 58:175-91.

Ruddick K, Neukermans G, Vanhellemont Q, Jolivet D, 2014. Challenges and opportunities for geostationary ocean colour remote sensing of regional seas: A review of recent results. Remote Sens Environ 146:63-76.

Soma K, Ramos J, Bergh Ø, Schulze T, Oostenbrugge H van, Duijn AP van, Kopke K, Stelzenmüller V, Grati F, Mäkinen T, Stenberg C, Buisman E, 2013. The "mapping out" approach: effectiveness of marine spatial management options in European coastal waters. ICES J Mar Sci 71:2630-42.

Trincardi F, Campiani E, Correggiari A, Foglini F, Maselli V, Remia A, 2014. Bathymetry of the Adriatic Sea: The legacy of the last eustatic cycle and the impact of modern sediment dispersal. J Maps 10:151-8.

Tuda AO, Stevens TF, Rodwell LD, 2014. Resolving coastal conflicts using marine spatial planning. J Environ Manage 133:5968. 